\title{
LA IGLESIA DEL COLEGIO DE NIÑAS
}

\author{
POR \\ GONZALO OBREGON
}

" $A$ DEmás del Colugio de San Juan de Letrán ... hay otro Colegio que A llaman de las Niñas, que se fundó con el mismo intento (para recoger niños pobres e hijot de españoles $e$ indias) y ahora hay recogidas en él muchas doncellas tobles y de alli las sacan para darles estado y casarlas. Estos dos Colegios cogen en medio San Francisco; el de los Niños a la parte del poniente $y$ el de las Niñas a la del oriente y están espalda con espalda y es la razón, porque por orden de los frailes de esta Orden fueron edificados e instituídos y aún al principio administrados."

Con estas palabras nos da razón Torquemada del Colegio de Niñas, de su razón de ser, de sus fundadores y de su situación en la capital de la Nureva España. No da fecha precisa pero se pueden establecer algunas que marcan los principios de esta institución, la primera en su género en América.

En 1538 se fundó en la capital de la Nueva España una Cofradia de caballeros, letrados y comerciantes para honrar al Santísimo Sacramento. Ocupa, después de la de la Santa Veracruz, erigida en 1526, el segundo 
lugar y al contrario de ésta, que fué en constante disminución, la del Santísimo aumentó año con año tanto en cofrades como en caudal. Esto le permitió en fecha no determinada con exactitud, pero que se puede fijar entre 1545 y 1548 , el tomar a su cargo el Colegio de Niñas mestizas conocido por Colegio de las Doncellas de Nuestra Señora de la Caridad, que originariamente había sido fundado por religiosos franciscanos, hacia 1532. Los inconvenientes que originaba su administración, hizo que quedara dependiendo de la Cofradía del Santísimo, que agregó a su advocación originaria la de Caridad y quedó y fué conocida, ya desde el siglo XVI, como "Archicofradía del Santísimo Sacramento y Caridad."

No es mi ánimo hablar en esta ocasión ni de esta Corporación que llegó a tener extraordinaria importancia, ni del Colegio en sí como institución. Me limitaré a describir las vicisitudes por las que pasó la iglesia de este Colegio del siglo XVI al xIx, y cómo ha llegado hasta nosotros. Los documentos que transcribo pertenecen al Archivo del Colegio de las Vizcaínas, a donde fué a parar el de la Archicofradia del Santísimo y, por ende, el del Colegio de las Doncellos. Van aquí mis agradecimientos a su encargada actual, la señorita profesora Julia Mörner.

El primer doctumento que nos habla indirectamente de la iglesia del Colegio de Niñas, es una escritura por la cual en agosto de 1552, Francisco Gómez, vecino de México, vende a la Cofradia del Santísimo unas casas entresoladas "en la calle que va de las casas de Juan de Cuevas al Colegio de los Niños de San Juan..." en la cantidad de $\$ 1,200.00$ de oro de minas.

La compra de estas casas aumenta considerablemente las casas primitivas en las que se había fundado el Colegio y nos permite fijar la situación que ocupa, a mediados del siglo xvI y que conservará hasta su desaparición. En la gran manzana que primitivamente ocupaba la casa de fieras de Moctezuma y cuya parte superior contenia al convento de San Francisco y sus dependencias, en la parte baja se encontraban las casas del Colegio. Una acequia que corria al norte y al poniente, separaba estas casas del convento. Al oriente daban a una calle que se llamó, ya desde el xvr, "del Colegio de las Doncellas". Al sur quedaron completadas estas casas por las compradas a Francişco Gómez y que, ya en 1570, permitieron dar a la calle el nombre de "calle de la Estampa del Colegio de Niñas".

Este mismo nombre nos indica la situación de la iglesia en el siglo xvi. Primitivamente esta capilla debió de haber sido arreglada en una de 
las salas del mismo Colegio, cuando se pensó en hacer de éste una institución permanente, se quiso tener iglesia con culto público. Quedó ésta situada ocupando la esquina sur-oriente dando a este lado toda la fachada $y$ al sur el ábside de la iglesia, en donde quedaba colocada "la estampa", relicve en piedra indicando el lugar en que estaba colocado el Santísimo.

Si hubiera alguna prueba de que ésta fué la situación de la iglesia hacia 1552-60, podría resultar que la primitiva iglesia del Colegio de Niñas, con su disposición en esquina y su fachada principal continuando la del Colegio, con dos puertas y espadaña, resultaria que pudo ser el prototipo de todas las iglesias monjiles que posteriormente se habian de edificar en la Nueva España.

En 1570 la Cofradia del Santísimo celebró contrato con el Maestro de Arquitectura Claudio de Arciniega, para reedificar las casas en las que el Colegio se había fundado. Ia elección de Arciniega se explica si tenemos en cuenta que en 1570 estaba como Maestro mayor de la obras de catedral y que la Cofradia (o Archicofradia como ya se empezaba a llamar) tenia en la misma Metropolitana su capilla titular. No se menciona expresamente en este contrato la iglesia del Colegio, tal vez esté incluida al hablar de las dependencias.

Dos años después, en 1572, se hizo un inventario minucioso de lo que poseía la iglesia. Gracias a él, sabemos que estaba adornada con cuatro retablos, tres de Nuestra Señora en tres diferentes advocaciones y uno dedicado al Santo Ecce Homo. Habia además dos imágenes de bulto de la Virgen, una pintura de la Verónica "en tabla, de Flandes"; un Misal y un İ̉bro de la Pasión. Existía tambièn un órgano pequeño con el que se oficiaba la Misa y en el coro once libros de danto para las colegialas. Como estos no eran suficientes, en 1580 se le pagaron a un indio "ocho pesos de oro común para hacer un libro grande de canto..."

En los dias de fiesta se engalanaba la iglesia con tapicerías. Encontramos, en efecto, en el mismo Inventario de 1572 que la encargada del Colegio, Beatriz de San Francisco, a la que los documentos llaman "Madre del Colegio", se da por recibida de las siguientes piezas :

"Seys paños grandes de tapizeria de Flandes con los triunphos del Petrarca."

"Otros ocho paños medianos, de ymágenes"

"Treynta y tres retratos de Flandes puestos en bastidor..." 
Está especificado en el mismo inventario que los tapices grandes y los medianos servian en la iglesia para las fiestas. Esto nos permite imaginar el maravilloso espectáculo renacentista que debió de ofrecer la nave de la iglesia adornada con las grandes tapicerías flamencas de los "Triomphi."

El resto de los tapices estaba colgado en las salas de labor o en el refectorio. Los treinta y tres retratos mencionados que ocasionalmente también se colgaban en la iglesia deben de haber sido o tapices pequeños o fragmentos de grandes tapicerías.

La iglesia debió de quedar maltratada a consecuencia de las inundaciones que ya empezaba a padecer la ciudad de México. A principios del siglo xvi se piensa en reedificarla, pero tan sólo se le repara. No es sino hasta 1612 que se le hacen obras de consideración, engrosando las paredes y cambiando el techo que se pone de "viguería labrada con artesón."

En 1637, a devoción de D. José de Cuenca y en recuerdo de su hija Da. Maria, mujer que habia sido de Martín de Sariñana, se puso en el presbiterio, del lado de la Epistola, un lienzo grande “de muy buen pinzel ..." representado de los Desposorios.

En junio de 1639 se acordó que los Rectores, Diputados y Mayordomos que "han sido $y$ fueron desta Santa Cofradía, les sirva de entierro el altar maior del dicho Colegio, de las gradas arriba, para que allí, queriendo, se pueden enterrar, e que lo tengan e conozcan por su entierro particular, e que puedan poner sus Armas, pues esta Santa Cofradia y sus Ministros, fundaron el dicho Colegio y lo están administrando e sustentando con tanto cuydado, dando de sus haziendas todo lo que ha menester ..."

Me consta que ninguno de los Mayordomos o Rectores hayan usado de esta facultad. Sin embargo, muchos de los cofrades del Santísimo, al morir, legaban diversas cantidades para dotaciones de huérfanas o para obras pías a juicio de la Mesa. Otros, igualmente, dejaban objetos para el Colegio. Un lote importante de caudros e imágenes sirvió en 1662 para renovar el colateral mayor de la iglesia. Tenemos el informe del Capellán dando noticia "de las cosas que se han puesto en el altar..." y que a la letra dice asi :

"Un colateral de cuatro varas de ancho $y$ seis de alto, de cuatro cuerpos. $Y$ en el primer cuerpo del sobrebanco, tres láminas, dos de media vara de ancho y tercio de alto, ambas de Nuestra Señora, y la de enmedio que está en la puerta del Sagrario, de Nuestro Señór después de azotado. Las de los lados tienen marcos de ébano." 
"El segundo cuerpo con una lámina de plata enmedio, de la carta que escribió la Virgen Santísima a los vecinos de la ciudad de Mesinas, sacada de buril, con marco de ébano; a los lados dos nichos, en uno, del lado del Evangetio, un Niño Jesús de bulto, de marfil, de media vara de alto con peaña de ébano y marfil ... y en el otro nicho una imagen de Nuestra Señora de casi tres cuarta de alto, con un vestido labrado, de labor ondeada de oro y seda encarnada y lentejuelas de oro, guarnecida de perias... con su corona imperial de plata sobredorada ... está sobre una peaña de ébano grande, con sobrepuestos, cartelas y bolas de plata con quince marcos de peso. Encima de la carta de la Virgen una lámina de Agnus Dei $y$ otras reliquias, en un cuadro de más de una tercia de alto, con su marco de ébano."

"En el tercer cuerpo enmedio una verónica, retrato de su Divino Rostro que se sirvió de inviar al Rey de los Abigaros, en lienzo, con marco de ébano de vara de alto y a los lados dos láminas del mismo tamaño, la una del Prendimiento del Señor y la otra del Calvario, con marcos de ébano."

"Y en el cuarto cuerpo con que se remata el altar, enmedio un Santo Cristo de marfil de casi dos tercias de alto con su cruz de ébano con cantoneras e INRI de plata. Está dentro de un marco forrado de terciopelo morado y adornos de plata en filigrana. A los lados dos laminitas de poco más de una cuarta con sus mascos de ébano..."

El altar, tal como está descrito, debió ser positivamente magnífico, resaltando sobre el oro del fondo el ébano de los marcos y el marfil de las imágenes. Se encuentran, en su descripción, algunos detalles curiosos como el del Divino Rostro que según la tradición medieval, Jesucristo envió al Rey de Abisinia, y la carta, tradición iguaimente medieval, que la Virgen María escribió a sus devotos de Messina.

En el año de 716 , el primer Capellán del Colegio, Br. José de la Barrera, dirigió a la Archicofradia un angustioso ocurso haciendo notar el mal estado de la techumbre de la iglesia. Esta databa de 1619, a menos que haya habido alguna reedificación posterior. Constaba de una sola nave, con cubierta de vigueria apoyada sobre zapatas y protegida al exterior por una gruesa lámina de plomo. El aspecto que debió de presentar, con su techumbre a dos aguas y una especie de cimborrio, lo podemos conocer por el plano de Pedro de Arrieta existente en el Museo de Chapultepec, que nos muestra iguaimente la espadaña que se alzaba en la actual esquina de 16 de Septiembre y Bolivar.

Acompañaba el Bachiller su escrito con una certificación jurada del Maestro de Arquitectura Juan de Peralta, en que describia el pésimo estado de casi toda la viguería, parte podrida y parte rota "sobre todo la que cai a la calle..." 
Pocos días más tarde, por comisión de la Archicofradía, el dicho Peralta junto con otros dos Maestros "del dho. Arte...", Antonio Alvarez y Juan Antonio de la Cruz, volvieron a reconocer la techumbre y estuvieron de acuerdo en que amenazaba grave riesgo.

La Archicofradía del Santísimo estuvo conforme en hacer la obra de reparación que quedó a cargo del Maestro Peralta y que consistió en reponer casi toda la vigueria "haziendo las zapatas o cabezas de las vigas molduradas y talladas como las antiguas..."

Sin embargo, ya toda la iglesia necesitaba un completo arreglo; en marzo de $174 !$ el Capellán del Colegio dirige un escrito a la Archicofradía exponiendo las necesidades de la iglesia y comienza asi :

"Primeramente el retablo maior de dicha iglesia que como tengo representando a VV. SS. en repetidas ocasiones, se haya tan maltratado que a más del peligro que amenaza e indecencia con que se celebra el Santo Sacrificio por la mucha polilla que despide, me he visto obligado a sacar el vaso del Sagrario, por ser éste nido de cacomitles y otras sabandixas..."

En vista de este escrito y de otro reconocimiento que se practicó, la Archicofradia del Santisimo decidió reconstruir totalmente la iglesia. Habia fondos suficientes y la obra debía de ser suntuosa y espléndida como correspondia a la importancia de sus miembros.

La obra se encomendó al Maestro de Arquitectura José Eduardo de Herrera. Existen todas las Memorias semanales de gastos y se puede a través de ellas, desde enero de 1742 hasta marzo de 1744, ver cómo avanzaba el edificio de la nueva iglesia. Fl arquitecto Herrera, con un excelente criterio, aprovechó los muros de la iglesia vieja, reforzándolos. El sistema de cimentación que usó y posiblemente el que se hayan utilizado también los gruesos cimientos del siglo xvi, hace que hasta la fecha esta iglesia no presente ninguna señal de hundimiento.

Las dos portadas fueron encomendadas al Maestro de Escultura Bernardo Romero, que las acabó el $1^{9}$ de diciembre de 1742 cobrando $\$ 275.00$ por cada una. Este mismo maestro se encargó de hacer la portada de la capilla de los Tejedores del "arte mayor de la seda", que se conocia también como capilla del Espiritu Santo.

Labradas ya las portadas, se encargó al maestro en carpintería Francisco Xavier Ramírez, la hechura de las puertas. En julio del mismo año se 
comprometio "solemnemente a hacerlas todas de cedro y la fábrica de dichas puertas ha de ser de frisos hundidos y molduras por fuera, y por dentro de chaflán, engargoladas y fuertes..." Para el adorno de estas puertas se aprovecharon los clavos de bronce de las antiguas y unos grandes escudos en bronce cincelado. El costo total fué de $\$ 466.00$.

Finalmente se envigó la iglesia, es decir, se le puso piso de madera con lugar para dieciocho sepulturas y el mismo maestro de carpintería quedó encargado de hacer la puerta de la sacristía, entablerada y la de la capilla, ésta de balaustres torneados. Igualmente se le encargó una cama destinada a los predicadores.

La iglesia se estrenó solemnemente en mayo de 1744 , con toque de chirimias, cohetes y luminarias, 30 arcos de tule para que pasara la procesión que verosimilmente vino de catedral, $y$, finalmente, para dar mayor esplendor a la función asistió la capilla catedralicia dirigida por el Maestro Antonio López de Cerezo, cantando la Misa, Salve y demás.

No sólo se había estrenado en esta ocasión la iglesia, sino también el magnifico retablo mayor, que tuvo un costo de $\$ 7,250.00$. Este fué obra del maestro don Felipe de Urueña y de su yemo Juan García de Castañeda. Urueña es conocido como maestro de Arquitectura ya que a él se le debe el proyecto de la iglesia de la Compañia de Guanajuato.

En la misma escritura se comprometió el maestro ensamblador a hacer "un púlpito de cedro blanco y nogal, con friso de tapincerán... y ciento veinticinco albortantes con sus almas de fierro y platillos de cobre para dicho retpblo, cuatro blandones con sus pedestales dorados y cuatro piñas doradas para las bóvedas de la iglesia ..." El costo de todo esto fué de $\$ 1,600.00$, habiendo quedado la obra del retablo y demás adorno bajo la Vigilancia de D. Manuel de Aldaco.

Para el adorno de la reja del coro se llamó a Juan Patricio Morlete Ruiz y se le encomendó un medio punto que habia de ocupar toda la parte alta, representando la Institución de la Eucaristía. El lienzo con su moldura ancha, tallada y dorada, costó $\$ 200.00$.

El ya citado Aldaco, que fué también uno de los fundadores beneméritos del Colegio de las Vizcainas, viendo en 1771 que habia fondos disponibles, propuso a la Mesa de la Archicofradia el emplear ese sobrante en completar el adorno de la iglesia con retablos laterales, encomendándolos al maestro ensamblador José de Sáyagos que acababa de terminar dos retablos laterales para la capilla del Colegio de San Ignacia 
Se aceptó la propuesta y se firmó un convenio privado entre la Archicofradia y dicho maestro. El convenio dice así :

"Digo yo, don José de Sáyagos, maestro de ensamblador y vecino de esta Ciudad que estoy convinado y ajustado con don Miguel alonso de-Hortigosa Rector de la M. Y. Archicofradia del Santisimo Sacramento y Caridad fundada en esta Santa Yglesia Metropolitana y Patrona del Colegio de Niñas Doncellas de Nuestra Señora de la Caridad, en fabricar y construir por la cantidad de doce mil pesos, cuatro altares con sus repisas o mesas, dorados y tallados con oro de tres panes que hallan de ocupar desde el pavimento de dicha Iglesia hasta la corniza de los cuatro arcos que se han mostrado, poniendo en cada uno de dichos retablos las inágenes, santos o santas' que dicho señor me ordenare, de talla o pintura según dispusiere, poniendo asimismo el arco de arriba de lienzos pintados al óleo, con sus marcos dorados, y los derrames de las ventanas tallados y dorados asimismo, a toda su satisfacción, dentro del término de diez meses que han de empezar a correr y contarse desde hoy, día de la fecha. $Y$ dicho señor Rector se obliga a irme entregando semanariamente según fuese demandando la construcción de dicha obra los pesos que le fuere pidiendo, los cuales al pié de esta obligación le haré, firmando para su resguardo los recibos de las cantidades que me fuere dando hasta la conclusión de la expresada fábrica, a todo lo cual me obligo en la más bastante forma que ha lugar en Derecho, con mi persona y bienes, habidos y por haber y para que conste en donde convenga firmé en México en 17 de mayo de 1771, siendo testigos don Manuel Escoto y Oliver $y$ don Ramón de San Juan Barroeta.

\section{Joseph Joaquin Sállagos" (rúbrica)}

Quedaron los retablos tan a la satisfacción del Rector, que éste propuso se le dieran de gala a Sáyago, la cantidad de $\$ 300.00$, cosa que se aceptó.

Entre la fecha del estreno de los colaterales y el año de 1792 en que se hizo un inventario general de la iglesia, no hay más que añadir sino el aumento ocasional de algunas piezas de plata.

Dicho inventario, levantado por orden de la Mesa, nos permite conocer el aspecto que of recía el interior de la iglesia de Nuestra Señora de la Caridad. Aun cuando los retablos han deasparecido, quedan en pie los de la capilla del Colegio de las Vizcainas que fueron hechos por el mismo Sáyago y en la misma época con una disposición bastante parecida, como lo podemos comprobar por el inventario.

El colateral mayor tenia, en el primer cuerpo, al centro, el tabernáculo de madera dorada adornado con veinte candeleritos de plata. El 
sotabanco, también en madera dorada, con seis blandones chicos dorados. A los lados entre columnas estípites, dos imágenes de talla, San José a un lado y del otro San Juan Bautista.

En el segundo cuerpo, en la parte central, había un nicho en el que, bajo cristales, se veía la imagen de Nuestra Señora de la Caridad, de media talla, con vestido de tisú de plata y manto azul bordado, colores que tambièn lucía el Niño Jesús. Se adornaba la Virgen con corona de plata dorada con esmeraldas y diversas joyas de valor entre las que sobresalían dos pulseras de perlas de veintísiete hilos cada una y un rostrillo en oro y perlas. El nicho tenía en la parte baja seis albortantes de cobre. A los lados dos esculturas de San Joaquín y Santa Ana, de talla estofada.

En el tercer cuerpo del retablo, un gran bajo relieve en madera representando la Visitación, festividad titular de la iglesia, entre dos ángeles de talla.

Tanto en el número de imágenes como en su disposición, este retablo mayor es tan parecido al mayor de Vizcainas que es muy posible que el autor sea el mismo Urueña. Cambian, tan sólo, los santos titulares ya que en vez del mencionado tablero está un. Santo Cristo y en el lugar de la Virgen de la Caridad estuvo, en el de Vizcainas, una Virgen de los Dolores, como titular de la capilla.

Volviendo al Colegio de $\mathrm{Niñas,} \mathrm{los} \mathrm{murọs} \mathrm{del} \mathrm{presbiterio} \mathrm{estaban} \mathrm{cu-}$ biertos por enormes pinturas enmarcadas en molduras doradas que los cubrian totalmente.

Venia inmediatamente en la nave, al lado de la Epistola, el altar del Sagrario. Este era en plata cincelada con adornos de espejos. En la parte central del colatral, en un nicho de cristales, tuna imagen de San José de media talla, con su túnico de raso bordado de oro y sedas, manto de tisú, vara y aureola de plata. A ambos lados San Felipe Neri y San Antonio de Padua de talla estofada. En el segundo cuerpo otras tres imágenes de talla de la Purísima, San Francisco y Santa Clara. En la parte alta cubrian el medio punto, dejando el hueco de la ventana, pinturas al óleo con su moldura dorada.

Frente a esta colateral estaba el de Nuestra Señora de la Luz, ésta en pintura, entre Santa Teresa y San Miguel de talla. En la parte alta un Santo Cristo de escultura con sus adornos de plata, entre la Virgen de los Dolores y San Juan Evangelista. Sólo la parte central era de talla y estaba rodeada de lienzos de la vida de la Virgen. La disposición de 
este retablo debió de haber sido muy semejante a la del altar de Loreto de la mencionada capilla de las Vizcainas.

Venían en seguida otros retablos, el primero dedicado a San Juan Nepomuceno. Esta imagen era de media talla y lo acompañában a los lados San Ignacio y San Francisco de Borja. En el cuerpo siguiente San Luis Gonzaga, San Juan Francisco Regis y San Estanislao. Repartidos en el retablo, cinco medallones de talla.

Frente a éste estaba el de Nuestra Señora de Guadalupe "de muy buen pinzel", con sus "albortantes" de cobre dorado. Como en el anterior, cinco imágenes de talla adornaban el retablo: San Diego y San Vicente Ferrer, San Agustín, San Jerónimo y San Ambrosio. Además cinco medallones de media talla con santos mártires.

En la reja del coro bajo estaban incrustados, entre adornos de madera dorada, dos óvalos con Santa Rosalia y Santa Rosa de Viterbo y dos cuadros rectangulares "de pinzel romano" con la Ascensión y la Resurrección del Señor.

La capillita del Espíritu Santo tenía también su retablo en madera tallada y dorada. Alrededor del cuadro de Pentecostés estaban repartidos los siete Arcángeles en talla, portando cada uno en las manos un emblema en plata dorada simbolizando uno de los Dones.

Sin ser muy rica la iglesia, estaba bien surtida en alhajas de oro y plata. El inventario menciona una custodia de plata sobredorada de una vara de alto con su relicario de oro guarnecido con dos cercos de piedras finas, otras dos custodias también de plata, tres copones, cuatro cálices, dos sagrarios de calamina y un juego de este mismo metal compuesto de un trono, un Santo Cristo, cuatro ramilleteros, seis blandoncitos, seis candeleros, etc. Habia, además, un trono grande de plata labrada que el inventario menciona como nuevo, es decir, que debió ser ya neoclásico, con quince candeleros y cuatro gradas.

Las alhajas de la Virgen eran muchas, además de las que tenia puestas de ordinario. Se mencionan ocho anillos de oro con esmeraldas, tres cruces, una de ellas con dieciséis rubies grandes rodeados de diamantes, el peluquín del Niño "con guarnición de perlas finas y cuatro flores de oro esmaltadas y tres lacitos de oro con diamantes rosa. La imagen estaba siempre vestida con esplendidez y su aspecto lo podemos conocer a través de una pintura de la primera mitad del siglo xviri, conservada en la actualidad en el Museo del Colegio de las Vizcainas. 
En esta época a la serie de alhajas y de ricos vestidos que ya poseia se agregaron los que habian pertenecido a la esposa de D. Joaquín Dongo, que antes de morir asesinado, habia instituido a la Archicofradia del Santísimo como heredera universal de todos sus bienes.

Las alhajas, vestidos y ornamentos de más valor se guardaban en la llamada "sacristía interior" que quedaba dentro del mismo Colegio y al cuidado de una de las colegialas. Lo necesario para la Misa se pasaba a los capellanes por un torno, con el mismo sistema que se seguía en los conventos de monjas.

En esta época la Archicofradía del Santísimo Sacramento y Caridad había llegado a ser la más importante de la capital, es decir, de la Nueva España. Tenía un capital de cerca de dos millones de pesos, administrando multitud de obras pías, entre ellas todas las que habian sido de la Congregación del Salvador, antes regida por los jesuítas. Este capital quedó, sin embargo, muy mermado en los primeros años del siglo XIX a consecuencia de los préstamos forzosos que hizo el Gobierno sobre los capitales de las fundaciones.

Durante los primeros años del México independiente disminuyó aún el capital, aunque se reponía lentamente gracias a una cuidadosa administración. En medio de todos los apuros pecuniarios, la Mesa de la Archicofradía trató de que nunca faltara al Colegio de Niñas nada de lo que fuera indispensable tanto para las educandas como para el servicio de la iglesia. El culto divino, en ésta, se siguió celebrando constantemente con esplembidez y buen gusto.

El interior de fa iglesia conservaba su antigua decoración, pero una serie de circunstancias iban a hacer que fuera completamente modificado entre 1846 y 184. Los "Libros de Actas" de la Archicofradia, nos han conservado las discusiones a que dió lugar este cambio. Las transcribo a continuación en sus partes esenciales:

\section{Cabildo de 17 de Jurio de 1843}

"El señor Icaza, como Maiordomo del Colegio, expone que siendo ya demasiado antiguo el Altar mayor de la Iglesia de éste, y necesitándose darle otra forma por el mismo decoro de la Archicofradía y a invitación de algunos señores, había hecho dibujar un modelo que presentó en el que a su juicio se concilian la economía y la decéncia, que si la $Y$. Mesa lo aprobara se procederá a la construcción del nuevo altar en los términos que manifiesta el mismo modelo que explicó a sus Señorias. Y discutido sobre el particular y del menor costo que podría sacar su construcción se facultó ampliamente al señor Mayordomo para que informado de 
algunos inteligentes, ordene de la manera que parezca mejor y que sea más económica para la Archicofradia la formación de dicho Altar mayor."

\section{Cabildo de 20 de Julio de 1843}

"Se leyó el acta del Cabildo de 17 de jumio... y el Señor Elizalde Ilamó la atención de la Y. Meza acerca de la falta de exactitud que se nota en ella al referir lo acordado sobre el altar mayor... ya que solo se determinó que informandose al propio señor lcaza del costo que ascenderia haciéndolo de madera y del que habría de importar si se huciere de piedra diere cuenta a la Y. Archicofradía para que esta resolviera lo que tuviera por conveniente.

Los demás seffores ratificaron este concepto y el señor Icaza hizo una circunstanciada relación de las poderosas razones que lo impulsaron a proyectar y proponer aquella obra, no llevándolo otra mira que la de evitar la crítica que se hace de esta Corporación por que no compone dicha iglesia, que casi es la única ya cuios altares conservan la forma anticuada que se les dió desde que se construyeron la primera vez.

Discutido largamente el particular y teniéndose en consideración que la obra importaría menos siendo de madera el altar, se acordó por la mayoría de los sefiores presentes que se haga así, contra la opinión del señor Icaza que estuvo por que se hiciera parte de madera y parte de piedra con arreglo al diseño que manifestó en el cabildo anterior y contra el parecer también del señor Agreda que votó por que se construyese el altar de piedra precisamente."

\section{Cabildo de 28 de Abril de 1845}

"El Administrador informó sobre el estado muy deteriorado en que se encuentra... la iglesia y colegio de Sta. Maria de la Caridad a consecuencia de los últimos temblores y se acordó haga formar un presupuesto del costo que tendrá su reposición, asociándose, por lo que respecta a la iglesia, con el señor Mayordomo del mismo Colegio, Diputado $\mathrm{D}$. José $\mathrm{Ma}$. Cervantes y presentando un diseño que pueda servir de norma para hacer de nuevo los colaterales de la primera, de modo que se concilie el gusto con la economía de su importe.".

\section{Cabildo de 4 de diciembre de 1845}

"El Sr. Rector recordó que el fin principal de este Cabildo, es resolver si se hace de nuevo el altar mayor y los colaterales de la iglesia del Colegio de Ntra. Sra. de la Caridad. Manifestó la necesidad que hay de que así se verifique tanto porque no parece regular que la Archicofradía mantenga dicha iglesia en el estado ridiculisimo en que se halla por su desaseo $y$ por la mucha antigüedad de sts altares, como porque habiéndose tenido que quitar algunos pedazos de estos para coger las cuarteaduras que abrieron en las paredes los ultimos temblores, se tienen que hacer gastos aún para dejarlo todo como antes y esos gastos se aprovecharian 
haciéndose las composturas que urgentemente reclaman el referido estado de la iglesia y el decoro de la Archicofradia.

El Sr. Rector... agrega solamente que la obra de que se trata no debe estimarse de mero adorno... sino de positiva y muy urgente necesidad, supuesto que no es posible ya tener abierta la iglesia... en el estado inmundo y asqueroso en que se encuentra ni tampoco es decente para la Archicofradia mandarla cerrar pretextando que no puede componerla, porque nadie lo creería, y aún cuando se le creyere, se diría con razón que todos en su caso han hecho un sacrificio y preferido agotar hasta el último recurso antes que cerrar sus templos, con perjuicio gravísimo del culto y privando al público de la utilidad que ellos le suministran. Que, y especialmente después de los horrorosos temblores habidos en el año que está para concluit, han tenido casi todos los conventos, colegios y párrocos, que componer sus iglesias y a pesar de que no todos cuentan con fondos abundantes para este gasto extraordinario, ningumo lo ha omitido y algunos a costa de excitar la caridad de los fieles y de sacrificios bastante considerables, han conseguido reparar aquellos y dejarlos en un estado regular de aseo y de ornato, dignos del objeto a que están destinados y del decoro de los encargados de su cuidado. Que, for lo mismo, la Archicofradia sería justamente acresdora a la crítica universal si, sabiéndose que no está en el caso de pedir limosna, como lo han hecho otros, no hiciere to que éstos y dejare la iglesia que está a su cargo más ridícula y asquerosa que ninguna, haciendo una excepción respecto de las dernás recién compuestas y apareciendo aquella como la única que podia recordar la forma y tosco adorno de los templos antiquísimos. Que por todo lo expuesto en consideración al deber en que considera a la Archicofradia de promover el aumento del culto y en obvio de esa justa crítica que es muy de temerse, puesto que se están manifestando en esta discusión los motivos que hay para ella, hace la siguiente proposición:

Se harán de nuevo el altar mayor y los colaterales de fa iglesia del Colegio de Ntra. Sra. de la Gridad, invirtiéndose en la obra la cantidad que designe la $Y$. Mesa, tomándola de loi sobrantes que resulten en poder del Administrador, satisfechos todos los gastos que ocurran durante la misma obra.

Después de discutido suficientemente el particular, se aprobó la proposición... Acto continwo infor ${ }^{*}$ el administrador sobre el importe de cada uno de los modelos y presupuestos que puso a la vista, formados por los Arqs. Hidalga, Téllez Girón. Miranda, Gualdi y otros, y considerándose que no es fácil para la corporación decidir sobre las ventajas o inconvenientes de cada uno de dichos presupuestos. se acordó nombrar una comisión que los examine detenidamente y elija el que ke pareciere mejor y acerca de la cantidad que pueda invertirse en la obra, estuvieron porque fuera, a lo más, hasta de $\$ 25,000.00 \ldots$

\section{Cabildo del 4 de febrero de 1846}

"El Sr. Rector como presidente de la Comisión encargada de dirigir la obra de la iglesia del Colegio de la Caridad, expuso: que después de haher examinado atentamente los planos de la dicha obra, que se presentaron en el Cabildo anterior y después tarnbién de haber procurado la mayor economía de los gastos necesarios para llevar a cabo, se decidieron a contrataria con el Arq. D. Lorenzo Hidalga, quien. 
aunque presentó un presupuesto importando $\$ 32,670.00$, quedó convenido en hacer la obra con total arreglo al mismo presupuesto y con algunas adiciones ventajosas para la Archicofradía por la cantidad de $\$ 28,500.00$ según lo expresa el documento que en seguida se copia:

\section{PRESUPUESTO DE LA OBRA DEL INTERIOR DE LA IGLESIA DEL COLEGIO DE NINAS}

La obra de carpinteria del colateral principal

La mesa' altar del inismo construída de piedra de chiluca su zócalo, y cornisa y el dado de canteria, con tableros de escayola imitando los me-

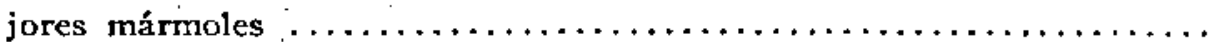

Por toda la decoración de los tableros, frisos y capiteles hechos de talla

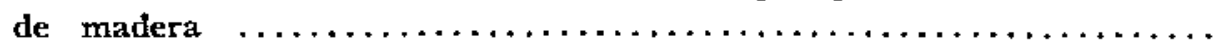

Por los casetones que forman el arco y las pilastras que terminan en la imposta con los arabescos, todo de estuco.

Por el dorado y pintura de todo el colateral

Por el importe de la carpintería de un colateral de los chicos

Por el importe de la mesa altar y zócalo, construídos de piedra de chiltuca,

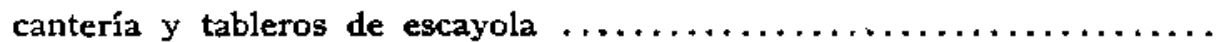

Por los adornos tallados en madera $\ldots \ldots \ldots \ldots \ldots \ldots \ldots \ldots \ldots \ldots \ldots \ldots \ldots \ldots$

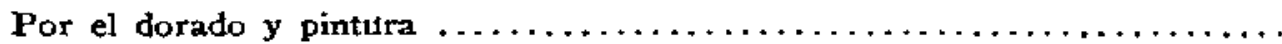

Importan los cinco altares restantes que son del mismo valor

Ror el estuco de la imposta general, el uno de los arcos y adornos de la cúpula

Por la obra de carpintería del piso y puertas

Por la pintura de las pechinas que se compondrá de cuatro Evangelistas y la de la cúpula que será una Gloria

\section{RESUMENES}

Importa el. colateral principal $\ldots \ldots \ldots \ldots \ldots \ldots \ldots \ldots \ldots \ldots \$ \$, 700.00$

Importe de uno chico $\ldots \ldots \ldots \ldots \ldots \ldots \ldots \ldots \ldots \ldots \ldots \ldots, \quad \mathbf{3 , 3 0 0 . 0 0}$

Importe de los cinco restantes ................ . 16,500.00 
Importe del estuco y demás adomos $\ldots \ldots \ldots \ldots \ldots \ldots \ldots$

Importe del $10 \%$ por la dirección $. . \ldots \ldots \ldots \ldots \ldots \ldots . . . . .$.

Total del presupuesto......
$4,200.00$

$2,970.00$

$\$ 32,670.00$

Acordaron los señores de la Convención con Hidalga en que construídos los altares y hecha la obra, según el anterior presupuesto y diseños presentados por el segundo, se pusiera en ejecución, "siendo además de su cuenta hacer el piso de la iglesia de madera engargolada de buena vista, componer la reja del coro, hacer una balaustrada nueva y de gusto en el presbiterio, igualar las ventanas del templo rasgando las que están sobre las puertas y encargándose ej Sr. Hidalgan de la compostura y construcción que sean necesarias de las imágenes que deberán colocarse en los altares según lo indica el referido diseño, excepto las que ocupen los lugares principales. Se le dará por todo esto la cantidad de $\$ 28,500.00$, entregando $\$ 6,000.00$ al contado y de $\$ 1,500.00$ a 2,000 mensuales $y$, además, todos los materiales de los altares viejos, incluso los santos y pinturas, excepto la imagen titular, Ntra. Sra. de Guadalupe, Ntra. Sra. de la Luz, La Purísima, Sr. San José y San Luis Gonzaga, que deberán colocarse en los mismos lugares en que estaban en cada aitar." En todo convino Hidalga y quedó ajustada la obra. El documento que nos habla de la apertura de la iglesia y de sus dificultades del momento es el siguiente:

"Razón de los términos en que se estrenó la iglesia del Colegio de Santa María de la Caridad, el 28 de noviembre de 1847 y disposición de los Srs. de la I. Mesa que se hallaban on la capital y que concurrieron.

"En consideración a las críticas circunstancias en que se encuentra la capital de la República por la guerra con los Edos. Unidos de Norte América, cuyas tropas entraron a ocupar esta ciudad el 14 de septiembre último, tomando los edificios racionales, casas principales y particulares como también varios conventos de religiosos de ambos sexos y como quiera que las cuantiosas sumas decretadas por el Supremo Gobierno Mejicano a las comunidades religiosas y corporaciones piadosas está señalada la I. Archicofradía... 'y sin fondos' hallándose lo principal, la iglesia del Colegio de Niñas ceycluida, y sus altares en disposición de celebrarse en ellos los Divinos Oficios... en este concepto queriendo evitar una ocupación que fundadathente se temió de las autoridades americanas y su maltrato por la falta de uso y ventilación... el domingo 28 del presente mes de noviembre a las 4 de la tarde, con asistencia de los frs. Diputados... se transladó el Smo. Sacramento desde la Sala Rectoral que hacia veces de oratorio, a la iglesia del mismo Colegio con la decencia y moderación posible. En efecto, reunidos a dicha hora los señores diputados, cmpleados, capellanes y colegialas, en forma de procesión y vela en mano todos, se hizo la citada traslación del Divinísimo Señor Sacramentado en procesión secreta y muy devota sin ningún canto, música ni demostración de regocijo exterior por no permitirlo las circunstancias más que las preces o salmos rezados, colocándose al Señor Sacramentado en el Sagrario del Altar mayor con lo que terminó el acto serio y respetuoso que exigía el caso."

Los documentos hasta aqui transcritos me parecen de la mayor importancia, parte por la serie de nombres de artistas que dan y de su parti- 
cipación en la obra de la iglesia, y parte también porque nos explican la desaparición de tantos altares barrocos acaecida por esos mismos años. No era sólo la estética predominante que hacia considerarlos anticuados y ridículos, sino la necesidad urgente de repararlos por lo maltratados que habían quedado a consecuencia de los temblores que padeció la capital entre 1830 y 1840 . Era casi tan costoso el componerlos (parte de estos altares churriguerescos debían estar ya apolillados) como el rehacerlos de nuevo dentro de las normas neoclásicas.

La iglesia del Colegio de Niñas fué muy alabada en su época y al analizarla trataremos de juzgar la obra que realizó el arquitecto Hidalga. Poco tiempo les duró a las educandas el disfrutar de ella, ya que fué una de las primeras instituciones suprimidas por la Reforma. El edificio deI Colegio fué vendido a particulares y la iglesia siguió en culto, aunque privada de todas sus alhajas, que fueron incautadas por el Gobierno. Las cosas de menor valor, como las pinturas y muebles del Colegio, pasaron al de San Ignacio, lo mismo que el riquísimo archivo de la Archicofradía.

Disuelta ésta, la iglesia pasó a poder de la Mitra, que la concedió a fines de siglo a la Colonia Francesa. Al tomarla, se le dió una relujada, hecha con el pésimo gusto característico de la época. Casi en nuestros días, la fachada fué restaurada con discreción, habiendo quedado en excelentes condiciones. Falta ahora, que el interior pueda encontrar otra vez su belleza.

La iglesia de Santa Maria de la Caridad ocupa un rectángulo, limitado al norte $y$ al oeste por las edificaciones que han sido levantadas aprovechando los muros del antiguo Colegio; al sur, sobre la calle de Venustiano Carranza, queda el ábside del que falta la "estampa" que alguna vez dió nombre a la calle $y$ la fachada principal da al oriente frente al jardín llamado vulgarmente del Reloj turco.

Esta fachada esta dividida en cinco tramos separados por contrafuertes en tezontle que separan los grandes espacios grises, en dos de los cuales, los más angostos, se pueden admirar dos portadas en cantera labrada, de idéntica disposición.

Estas portadas están compuestas de los mismos elementos. A ambos lados de la puerta, con arco de medio punto, dos curiosas pilastras estipites, que dan la impresión de incompletas, ya que en vez de la parte superior con el clásico remate de capitel corintio, hay un gran bajo relieve en el que están de un lado San Joaquín y la Virgen niña y, del otro, la misma Virgen con Santa Ana. El frontón circular que corona este primer cuerpo 
da lugar en la parte central a una cartela con un letrero "SANTA MARIA DE LA CHARIDAD - ANOO DE 1744." En la parte superior otro bajo relieve con la escena de la Visitación, con cuatro personajes. Este relieve, ricamente encuadrado con molduras, está acompañado a los lados de dos pináculos vagamente herrerianos y dos grandes volutas que salen del muro y parecen limitar la portada.

I.a otra es idéntica. Varían los asuntos de los relieves, ya que en vez de San Joaquín y Santa Ana, están San Pedro y San Pablo, y en lugar de la Visitación vemos el Bautismo de Cristo. La cartela, bajo de ésta, dice: "SACROSANTA LATERANENSE ECCLESIAE."

Tal como podemos ver las portadas en la actualidad, dan la impresión de incompletas, y es cierto. En el lugar que ocupan las ventanas abiertas en la reforma del Arq. Hidalga, debieron de existir unos escudos con las insignias de la Cofradía del Santísimo Sacramento, es decir, una custodia entre resplandores. $\mathrm{La}_{\mathrm{a}}$ falta de este remate hace que las portadas se vean truncas.

Desde el mismo jardín del Colegio de Niñas se distingue la curiosa cúpula de la iglesia, que es de platillo sin ventanas y tan solo con ina linternilla. Llama igualmente la atención la falta de torre o de espadaña. Esta existió y estaba colocada en la esquina del Colegio, en Bolivar y 16 de Septiembre, y asi la podemos ver en dos planos del siglo xvirr de la Colección del Museo de Chapultepec.

$\mathrm{Si}$ el exterior de la iglesia no hace mucho honor a la fantasía creadora de su autor el Arq. Eduardo de Herrera, el interior, en cambio, es muy hermoso. Tenemos una esbelta nave de cinco tramos, de excelentes proporciones y que da una impresión de ligereza a pesar de sus arcos muy rebajados. $\mathrm{Na}$. presenta ninguna novedad arquitectónica $\mathrm{y}$ repite el tipo tan frecuente ef las iglesias capitalinas de la misma época. Cada tramo está cubierto cón bóveda de arista y el inmediato al presbiterio con la cúpula de platillo que se distingue al exterior. El capitel que corona cada pilastra, que es bien sencillo, se continúa como moldura dando vuelta a la nave. Uno de los tramos de ésta está lastimosamente cortado por un coro postizo. Se conoce que el coro antiguo quedaba dentro del edificio del Colegio y al ser vendido éste en la época de la Reforma y quedando sin coro la iglesia, se vieron obligados a hacer el existente.

Todo el interior de la iglesia que debió de ser extraordinariamente luminoso, ha quedado desfigurado por unos feísimos vitrales modernos que causan una penumbra constante. Estos vitrales datan de la época en que 
la iglesia fué convertida en parroquia de la colonia francesa. De esta misma época data la decoración de las bóvedas, ejemplo acabado de ma1 gusto.

Subsiste, sin embargo, íntegra la obra que proyectó D. Lorenzo de la Hidalga : el retablo principal, complementado por los retáblos laterales.

El primero ocupa todo el fondo del ábside de la iglesia. Está encuadrado por dos pilastras laterales, marmoleadas, como las demás de la iglesia, pero con la diferencia de que éstas están cubiertas de grutescos de tipo italiano, dorados. Las pilastras se continúan y dan vuelta a la bóveda del presbiterio, presentando un adorno de casetones con grandes flores. Todo este ornato forma al retablo una especie de rico marco, en mármoles y oro. El altar propiamente dicho se compone de un basamento y tres cuerpos. En profundidad, hay igualmente tres planos, y la importancia del central es acentuada por el empleo de columnas, mientras que en las calles laterales se usan sólo pilastras. En esta parte central están colocadas las imágenes que deben atraer la atención de los fieles. En el primer cuerpo queda el bueco para el expositor, ligado por tunas gradas a la mesa de oficiar, en el segundo, la imagen titular de Nuestra Señora de la Caridad $y$ en el tercero, como remate, un gran tablero de media talla representando la Visitación. Esta escultura, de excelente calidad, es posible que sea la misma que encontramos mencionada en los retablos del siglo xvir y en el que le sucedió. Su composición general, la nobleza de las figuras, la calidad de los esmaltes, sobre todo en las caras y las manos, dan la impresión de una magnifica obra barroca.

E1 conjunto general del retablo, hace también pensar en un retablo barroco, más que en una obra neoclásica. La división en tres cuerpos, el uso de columnas y pilastras pequeñas, el empleo del color y del dorado le confieren una indudable originalidad. Basta comparar esta composición con los típicos altares neoclásicos, con sus gigantescas columnas, que parecen arrancadas de Baalbeck, sus santitos minúsculos, su adorno parsimonioso y sus inevitables frontones. Todo esto está evitado en este retablo, que continúa en forma sorprendente, la tradición de los altares barrocos del siglo xvrr.

La impresión general que produce, en quien lo contempla detenidamente, es una obra equilibrada y armónica. Lástima que esta sensación se vea rota por una serie de adiciones de mal gusto que ha sufrido en los últimos años, como el exceso de candeleros corrientes, de flores de papel; de falsos ramilleteros o el aspecto lamentable de la patrona de la iglesia, la 
Virgen de la Caridad, vestida de manta blanca, como un camisón. Y es, sin embargo, la misma imagen que hemos visto tan ricamente ataviada. De sus antiguas magnificencias conserva tan sólo sus zapatos, en tisú de plata con bordados en oro.

El presbiterio queda separado de la nave por un barandal de la misma época y que es un bonito ejemplo de decoración con elementos de gusto Imperio. El púlpito en cambio, más que púlpito parece jaula.

A lo largo de la nave hay seis altares, que repiten, en forma más sencilla, las líneas generales del altar mayor. Sobre una base lisa, pintada en imitación de mármol gris y café, se levanta un cuerpo central, limitado por dos columnas corintias que sostienen un entablamento. Este se prolonga a los lados, con menos relieve, sostenido por dos pilastras, que hacen juego con las columnas del cuerpo central. Las pilastras están ornamentadas con grutescos de tipo italiano de medio relieve, dorados, que se destacan sobre un fondo rojo oscuro, el famoso "rojo pompeyano" tan del gusto de la época. La parte central de estos retablos está destinada a una imagen en pintura y a los lados, dos esculturas en madera policromada.

La composición, como se puede ver, es muy sencilla. La igualdad de estos retablos confiere a la iglesía un carácter de armonía y de unidad muy raramente logrado en las iglesias capitalinas. Es de lamentar que en vez de las esculturas originales los capellanes de la iglesia hayan colocado una serie de santos franceses del peor estilo "saint Sulpice", cubriendo muchas veces las pinturas originales con trapos y colgaduras. Es también de lamentar que esta iglesia, como la inmensa mayoria de las de México, por la profusión de jmágenes de moda se haya convertido, como decía Huysmans en un "basurero devoto".

Sólo queda poł desear que una cuidadosa restauración -muy fácil además- pueda devolver a esta iglesia su dignidad y su belleza. No sólo lo amerita por su historial, sino que puede quedar como un bello ejemplo de arte religioso en la primera mitad del siglo xIX. 


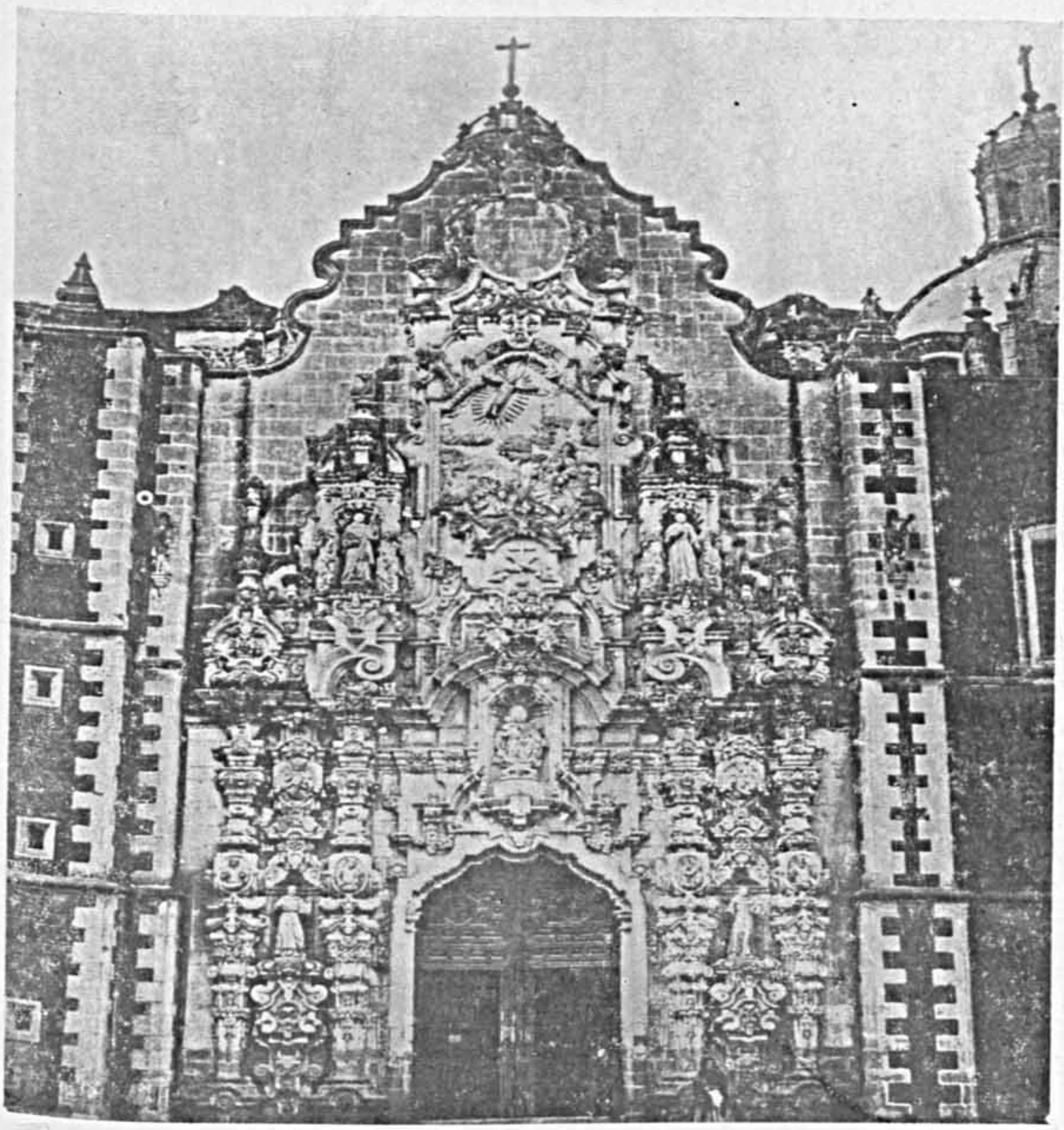

1. Portada de la Capilla de Baivanera. 


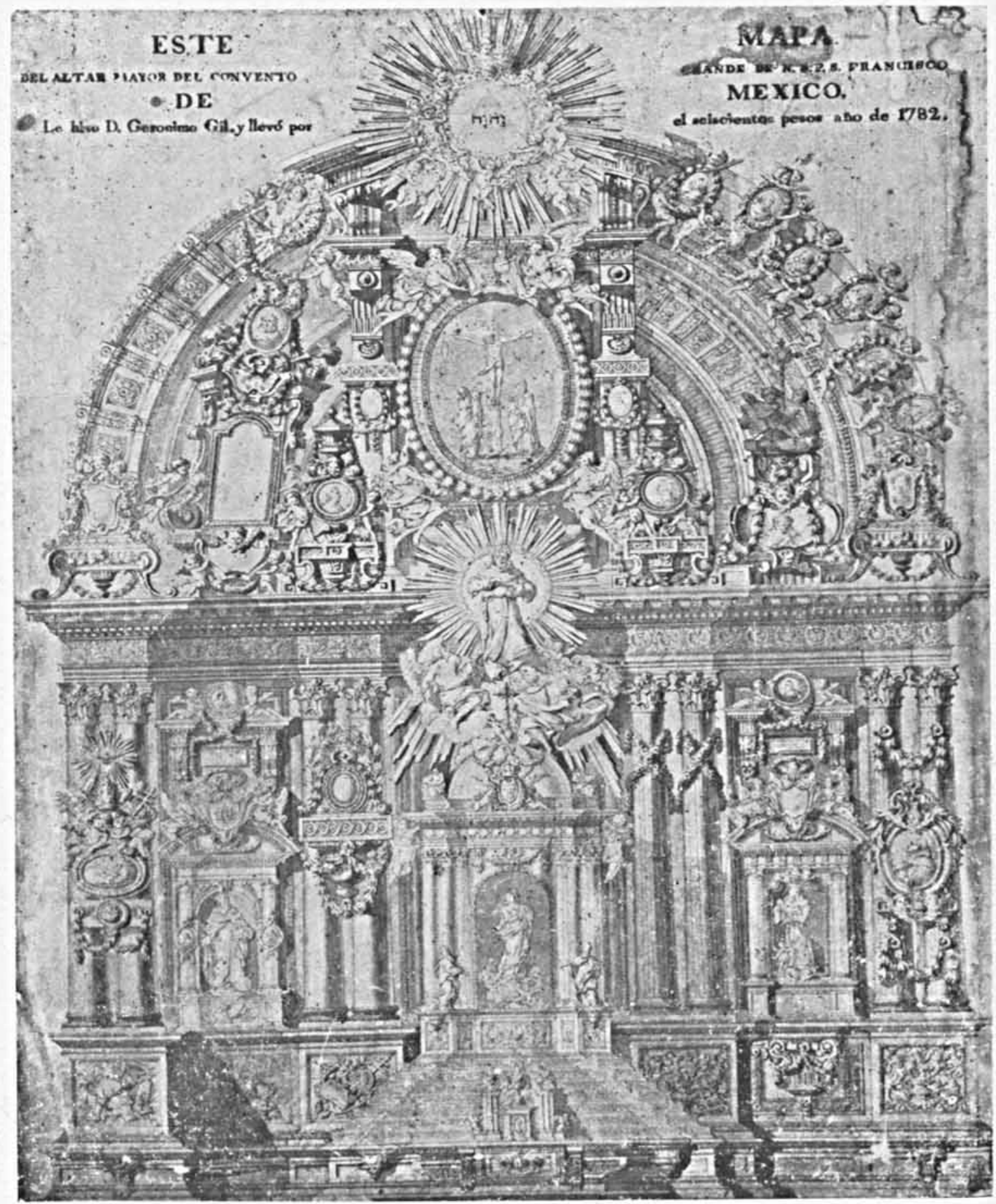

2. Proyecto para el Altar Mayor. 


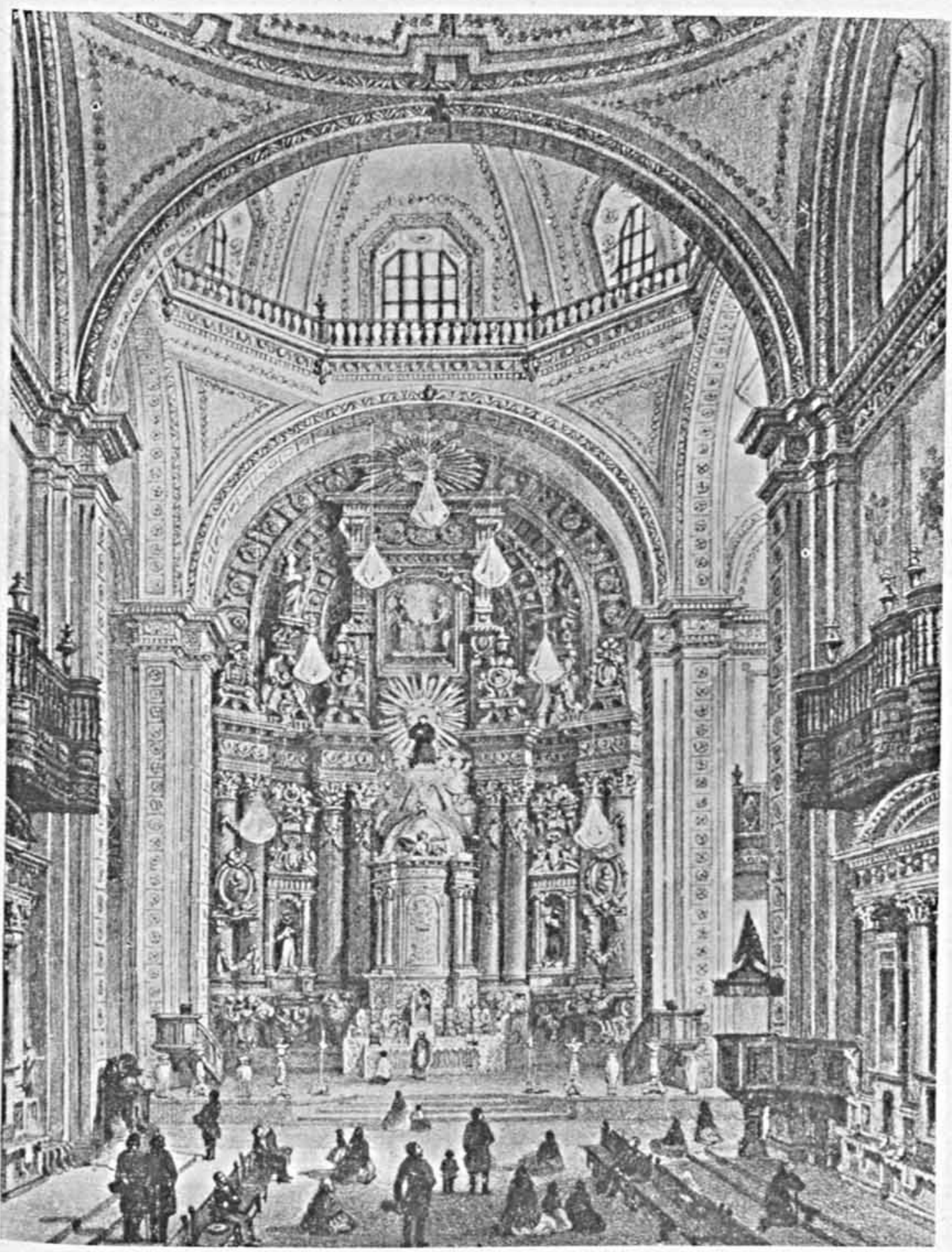

3. Altar Mayor de la Iglesia de San Francisco. 


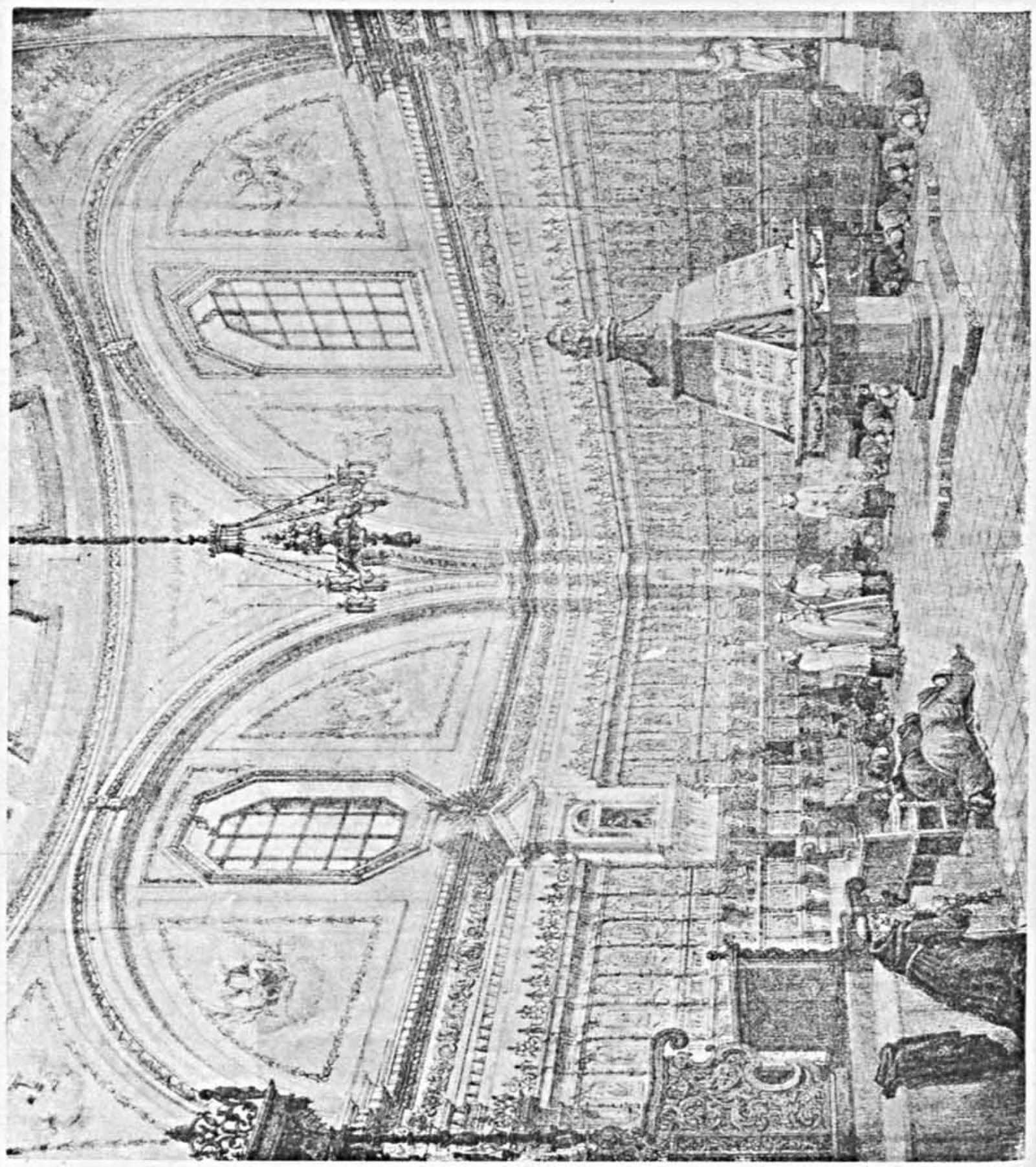

